\title{
Antibacterial Susceptibility Pattern of Bacteria Isolated from Retail Fish in Okada, Edo State Nigeria
}

\author{
Jesumirhewe, $\mathbf{C}^{1 *}$ \& Ibeh, N. L. ${ }^{2}$ \\ 1*Jesumirhewe C, Department of Pharmaceutical Microbiology, College of Pharmacy, Igbinedion University \\ Okada, Edo state Nigeria
}

${ }^{2}$ Department of Pharmaceutical Microbiology

College of Pharmacy, Igbinedion University Okada, Edo state

Nigeria

\begin{abstract}
This study aimed at the microbiological analysis of retail frozen and smoked fish in Okada Edo state Nigeria. Four different retail fish samples were collected from different point of sale in Okada market. Two fresh iced and smoked samples respectively were used for the study. After sub culturing prepared samples into appropriate media, 38 bacterial isolates were obtained from primary culture plates and characterized using standard microbiological methods. Antimicrobial susceptibility tests were performed on the isolates using the Kirby-Bauer disc diffusion method. All the isolates obtained were Gram positive cocci bacteria and had a probable identity of Streptococcus sp, Staphylococcus sp and Coagulase negative Staphylococcus sp. The fresh fish samples had a minimum viable count of $1.7 \times 10^{6} \mathrm{cfu} / \mathrm{g}$ and a maximum count of $4 \times 10^{6} \mathrm{cfu} / \mathrm{g}$ while the smoked fish samples had a minimum viable count of $1.8 \times 10^{6} \mathrm{cfu} / \mathrm{g}$ and a maximum count of $8.5 \times 10^{6} \mathrm{cfu} / \mathrm{g}$. Results from this study shows that the samples do not meet the acceptable limit $\left(5 \times 10^{5} \mathrm{cfu} / \mathrm{g}\right)$ of the International Commission of Microbiological Specification for Food (ICMSF). The antibiotic susceptibility test showed the presence of antibiotic resistant organisms among the retail fish samples. The detection of high viable counts of bacteria isolates beyond acceptable limits and their antibiotic resistance pattern elucidates the need for continuous monitoring of retail sea foods in the environment. Prudent use of antibiotics in aquaculture should be promoted to avoid the public health impact caused by antibiotic resistance transferred from retail sea foods to humans.
\end{abstract}

Key Words: Microbiological analysis, Retail fish, Microorganisms, Antibiotic resistance, Public health.

\subsection{INTRODUCTION}

Fish is a food that has excellent nutritional value, providing high quality protein and a wide variety of vitamins and minerals, which includes vitamins $\mathrm{A}$ and $\mathrm{D}$, phosphorous, magnesium, selenium and iodine in marine fish. It's a protein-like meat that can be easily digestible and complements dietary protein provided by cereals and legumes that are typically consumed in many developing countries like Nigeria. It is a particularly important protein source in regions where livestock is relatively scarce. Fish has been reported to supply $<10 \%$ of animal protein consumed in North America and Europe, but 17\% in Africa, 26\% in Asia and $22 \%$ in China [1]. Aquaculture appears to be one of the last frontiers to increase contributions to food security in the developing world. To meet the ever-increasing demand for fish, aquaculture has expanded very rapidly and now represents the fastest growing agricultural industry in some countries, with freshwater aquaculture dominating total aquaculture production. For example, this global picture is reflected in Africa where aquaculture supply high quality food at low cost to millions of people, generate income for farming and fishing households and play a central role in many local and national economies [2]. Fisheries and aquaculture provide an important source of food and livelihoods for more than one billion people globally. Aquaculture has been reported to be one of the fastest growing food production sectors in the world [3]. Its increasing global importance is directly related to the contribution it makes to reduce the gap between supply and demand for fish production. A previous report by "Reference [4]", asserted that fish contributes about $60 \%$ of the world supply of protein and that $60 \%$ of the developing world derives more than $30 \%$ of their animal protein from fish. Fish are generally regarded as safe nutritious foods but products from 
aquaculture have sometimes been associated with certain food safety issues [5]. "Reference [6]" reported that an increase in the production of fish increases the likelihood of and severity of parasites and disease outbreaks, which is a major challenge to aquaculture production. The continuous pollution of the aquatic environment also increases the likelihood of infection; untreated wastes are deposited on the ground, washed away by rainwater and discharged into nearby natural water bodies and ponds [7]. A large number of fish species, both marine and freshwater are potential sources of medically important zoonotic diseases [8]. Some of these diseases are highly pathogenic; and the main cause of human infection is the interaction of man with this organisms both in the consumption of raw or inadequately cooked fish or during processing $[9,10]$.

The use of antimicrobials has played an important role in treatment and growth promotion in the aquaculture industries [11]. Antibiotics are used in aquaculture to treat diseases caused by bacteria [12] but more commonly antibiotics are used for prophylaxis by treating the water or fish before diseases occur [13]. While the prophylactic method of preventing disease is profitable as it prevents loss and allows fish to grow more quickly, the overuse of antibiotics can create antibiotic- resistant bacteria. Antibiotic resistant bacteria can spontaneously arise when selective pressure to survive results in changes to the DNA sequence of the bacterium allowing that bacterium to survive antibiotic treatments. Pathogenic bacteria causing human disease can also become resistant to antibiotics as a result of treatment of fishes with antibiotics as some of the same antibiotics used in aquaculture are also used for treatment in humans [14]. The overuse of antibiotics in aquaculture (among other agricultural uses) could create public health issues [15]. According to a previous report by "Reference [16]", most fish related food borne illness are traced to Salmonella, Staphylococcus sp, Escherichia sp, Vibrio, Parahaemolyticus, Clostridium perferenges and Enteroviruses [17]. Treating antimicrobial resistant bacterial infections as a result of consumption of contaminated aquaculture products can be difficult. It undermines empirical treatment regimens, thereby delaying the options and administration of appropriate antibiotic therapy. This also contributes to increased patient morbidity and mortality. Hence monitoring of sources of antimicrobial resistance is necessary especially in developing countries like Nigeria that have inadequate data as regards various sources of antimicrobial resistance. The aim of this work was to determine the frequency of possible organisms in retail fish obtained from Okada markets and determine the antimicrobial susceptibility of such isolates.

\subsection{MATERIALS AND METHODS}

\subsection{Sample collection}

The fish samples were collected between April-May, 2019. Four different retail fish samples were obtained from different point of sale in Okada market. Two fresh iced and smoked samples respectively were obtained for the study. The fish samples were aseptically collected in sterile polythene bags and transported to the laboratory for microbiological analysis. The samples were processed within an hour of collection.

\subsection{Microbiological evaluation of samples}

The skin of the fish samples was aseptically scraped using procedures described by "Reference [18]". Samples were prepared using a previously described method by "Reference [19]" with little modifications. The fish samples were cut from the head, middle and tail regions using a sterile knife and mashed in a sterile laboratory type mortar with pestle. From the crushed samples, a gram of each sample was weighed and a tenfold serial dilution was prepared for the microbiological analysis of the samples. The samples were inoculated on Nutrient agar and MacConkey agar plates. All plates were incubated at a temperature of $37^{\circ} \mathrm{C}$ for 24 hours. The plates were examined for bacterial growth through formation of isolated colonies. Visible colonies were counted to obtain the total viable count on each plate. Discrete colonies were picked out. Isolates were identified and characterized based on their cultural characteristics, colonial and microscopic appearance and biochemical reactions. Standard microbiological/biochemical methods were used in the identification of bacteria [20]. The Biochemical tests included Gram staining reaction, Citrate, Catalase, Coagulase and Oxidase test.

\subsection{Antimicrobial sensitivity test}

The Kirby-Bauer susceptibility testing technique [21] was carried out. Isolates were cultured on Nutrient agar overnight at $37^{\circ} \mathrm{C}$. The inoculum was adjusted to McFarland 0.5. The isolates were tested with 8 antibiotics which include; Ofloxacin(5 $\mu$ g),

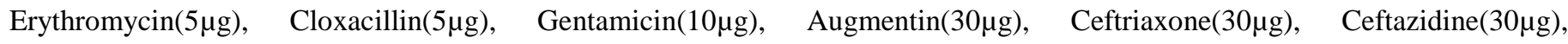
Cefuroxime $(30 \mu \mathrm{g})$ on Mueller Hinton agar plates. Incubation was performed at $37^{\circ} \mathrm{C}$ for 24 hours and results were also interpreted using EUCAST criteria [22].

\subsection{RESULTS}


The viable colony count (cfu/g) of the samples showed that smoked fish samples had higher colony count than that of the frozen fish samples. Table 1 shows the viable colony count for the frozen and smoked fish samples.

Table 1 Viable colony count for the frozen and smoked fish samples.

\begin{tabular}{ll}
\hline Fish samples & Viable colony count $(\boldsymbol{c f u} / \mathbf{g})$ \\
\hline$T 1$ & $1.7 \times 10^{6}$ \\
$T 2$ & $4 \times 10^{6}$ \\
S1 & $1.8 \times 10^{6}$ \\
S2 & $8.5 \times 10^{6}$ \\
\hline Key T-Fresh fish sample, S-Smoked fish sample &
\end{tabular}

Out of the four samples examined, thirty eight distinct isolates were obtained from the various isolates observed from the primary plates. The identified bacteria obtained from the fish samples include Staphylococcus sp, Coagulase negative Staphylococcus sp and Streptococcus sp. Streptococcus $s p$ was the most prevalent bacteria isolated from the samples especially the smoked fish samples. Table 2 shows the frequency distribution of the isolates from the fish samples.

Table 2 Frequency distribution of the isolates from the fish samples

\begin{tabular}{lll}
\hline Isolates & No of isolates & Frequency \% \\
\hline Staphylococcus sp & 3 & $7.9 \%$ \\
Coagulase negative Staphylococcus & 2 & $5.3 \%$ \\
sp & & \\
Streptococcus sp & 33 & $86.8 \%$ \\
\hline
\end{tabular}

Using the European Committee on Antimicrobial Susceptibility Testing (EUCAST guidelines) for determining susceptibility, the antimicrobial susceptibility test showed the presence of resistant isolates to antibiotics examined (Table 3 and 4 ).

Table 3 Antibiogram of isolates from the Smoked fish samples

\begin{tabular}{|c|c|c|c|c|c|c|c|c|c|}
\hline$S / N$ & Isolate & $\begin{array}{l}\text { Caz } \\
30 u g\end{array}$ & $\begin{array}{l}\text { Crx } \\
30 u g\end{array}$ & $\begin{array}{l}\text { Gen } \\
\text { loug }\end{array}$ & $\begin{array}{l}\text { Ctr } \\
30 u g\end{array}$ & $\begin{array}{l}\text { Ery } \\
5 u g\end{array}$ & $\begin{array}{l}\text { Ofl } \\
5 u g\end{array}$ & $\begin{array}{l}\text { Aug } \\
30 u g\end{array}$ & $\begin{array}{l}\text { Cxc } \\
5 u g\end{array}$ \\
\hline 1 & Strep $s p$ & $R$ & $R$ & $R$ & $R$ & 10 & $17^{X}$ & $R$ & $R$ \\
\hline 2 & Strep sp & $R$ & $R$ & $R$ & $R$ & $R$ & 20 & $R$ & $R$ \\
\hline 3 & Strep sp & $R$ & $R$ & $R$ & $R$ & $R$ & 15 & $R$ & $R$ \\
\hline 4 & Strep sp & $R$ & $R$ & $R$ & $R$ & $R$ & 29 & $R$ & $R$ \\
\hline 5 & Strep sp & $R$ & $R$ & $R$ & $R$ & 10 & 38 & $R$ & $R$ \\
\hline 6 & Strep sp & $R$ & $R$ & $R$ & $R$ & $R$ & $R$ & $R$ & $R$ \\
\hline 7 & $\begin{array}{l}\text { CoN } \\
\text { Staph } \\
\text { sp }\end{array}$ & $R$ & 10 & $R$ & $R$ & 11 & $R$ & $R$ & $R$ \\
\hline 8 & Strep sp & $R$ & $R$ & $R$ & $R$ & $R$ & 30 & $R$ & $R$ \\
\hline 9 & $\begin{array}{l}\text { CoN } \\
\text { Staph } \\
\text { sp }\end{array}$ & $R$ & $R$ & $R$ & $R$ & $R$ & 19 & $R$ & $R$ \\
\hline 10 & Strep sp & $R$ & $R$ & $R$ & $R$ & $R$ & 20 & $R$ & $R$ \\
\hline 11 & Strep sp & $R$ & $R$ & $R$ & $R$ & $R$ & $R$ & $R$ & $R$ \\
\hline 12 & $\begin{array}{l}\text { Strep } \\
s p\end{array}$ & $R$ & $R$ & $R$ & $R$ & $R$ & 29 & $R$ & $R$ \\
\hline 13 & $\begin{array}{l}\text { Strep } \\
s p\end{array}$ & $R$ & $R$ & $R$ & $R$ & $R$ & 20 & $R$ & $R$ \\
\hline 14 & $\begin{array}{l}\text { Strep } \\
s p\end{array}$ & $R$ & $R$ & $R$ & $R$ & $R$ & $R$ & $R$ & $R$ \\
\hline 15 & $\begin{array}{l}\text { Strep } \\
\text { sp }\end{array}$ & $R$ & $R$ & $R$ & $R$ & $R$ & $R$ & 5 & $R$ \\
\hline 16 & Strep sp & $R$ & $R$ & $R$ & 9 & 22 & 33 & $R$ & $R$ \\
\hline 17 & Staph & $R$ & 20 & $R$ & $R$ & 15 & $R$ & $R$ & $R$ \\
\hline
\end{tabular}


International Journal of Advances in Scientific Research and Engineering (ijasre), Vol 6 (4), April -2020

\begin{tabular}{|c|c|c|c|c|c|c|c|c|c|}
\hline 18 & Strep & $R$ & $R$ & $R$ & $R$ & 13 & $R$ & $R$ & $R$ \\
\hline & $s p$ & & & & & & & & \\
\hline 19 & Strep & $R$ & 11 & $R$ & $R$ & 24 & $R$ & $R$ & $R$ \\
\hline 20 & $\begin{array}{l}s p \\
\text { Strep } \\
s p\end{array}$ & $R$ & $R$ & $R$ & $R$ & $R$ & 11 & $R$ & $R$ \\
\hline 21 & strep sp & $R$ & $R$ & $R$ & $R$ & 15 & 32 & $R$ & $R$ \\
\hline 22 & $\begin{array}{l}\text { Strep } \\
s p\end{array}$ & $R$ & $R$ & $R$ & $R$ & $R$ & 22 & $R$ & $R$ \\
\hline 23 & $\begin{array}{l}\text { Strep } \\
s p\end{array}$ & $R$ & $R$ & $R$ & $R$ & $R$ & $R$ & $R$ & $R$ \\
\hline 24 & $\begin{array}{l}\text { Strep } \\
s p\end{array}$ & $R$ & $R$ & $R$ & $R$ & $R$ & 30 & $R$ & $R$ \\
\hline 25 & $\begin{array}{l}\text { Staph } \\
s p\end{array}$ & $R$ & $R$ & $R$ & $R$ & $R$ & $R$ & $R$ & $R$ \\
\hline 26 & $\begin{array}{l}\text { Strep } \\
s p\end{array}$ & $R$ & $R$ & $R$ & $R$ & $R$ & 25 & $R$ & $R$ \\
\hline 27 & $\begin{array}{l}\text { Strep } \\
s p\end{array}$ & $R$ & $R$ & 9 & $R$ & 19 & $R$ & $R$ & $R$ \\
\hline 28 & Strep $s p$ & $R$ & $R$ & $R$ & $R$ & $R$ & 30 & $R$ & $R$ \\
\hline 29 & $\begin{array}{l}\text { Strep } \\
s p\end{array}$ & $R$ & $R$ & $R$ & $R$ & $R$ & 18 & $R$ & $R$ \\
\hline 30 & Strep $s p$ & $R$ & $R$ & $R$ & $R$ & $R$ & 19 & $R$ & $R$ \\
\hline
\end{tabular}

Table 4 Antibiogram of isolates from the fresh fish samples

\begin{tabular}{|c|c|c|c|c|c|c|c|c|c|}
\hline$S / N$ & Isolates & $\begin{array}{l}\mathrm{Caz} \\
30 \mu \mathrm{g}\end{array}$ & $\begin{array}{l}C r x \\
30 \mu g\end{array}$ & $\begin{array}{l}\text { Gen } \\
10 \mu g\end{array}$ & $\begin{array}{l}\text { Ctr } \\
30 \mu g\end{array}$ & $\begin{array}{l}\text { Ery } \\
5 \mu g\end{array}$ & $\begin{array}{l}\text { Ofl } \\
5 \mu g\end{array}$ & $\begin{array}{l}\text { Aug } \\
30 \mu g\end{array}$ & $\begin{array}{l}C x c \\
5 \mu g\end{array}$ \\
\hline 1 & Strep $s p$ & $R$ & $R$ & 17 & $R$ & $R$ & 22 & $R$ & $R$ \\
\hline 2 & Strep $s p$ & $R$ & $R$ & 22 & $R$ & $R$ & $R$ & $R$ & $R$ \\
\hline 3 & Strep $s p$ & $R$ & $R$ & $R$ & $R$ & $R$ & $R$ & $R$ & $R$ \\
\hline 4 & Strep $s p$ & $R$ & $R$ & $R$ & $R$ & $R$ & 25 & $R$ & $R$ \\
\hline 5 & Staph $s p$ & $R$ & $R$ & $14^{X}$ & $R$ & $R$ & 19 & $R$ & $R$ \\
\hline 6 & Strep $s p$ & $R$ & $R$ & $R$ & $R$ & $R$ & 18 & $R$ & $R$ \\
\hline 7 & Strep $s p$ & $R$ & 10 & 7 & $R$ & 10 & $R$ & $R$ & $R$ \\
\hline 8 & Strep $s p$ & $R$ & $R$ & $R$ & $R$ & 15 & $R$ & $R$ & $R$ \\
\hline
\end{tabular}

Key: Cxc- Cloxacillin, Gen- Gentamicin, Ctr- Ceftriaxone, Ery- Erythromycin, Caz- Ceftazidine, Ofl- Ofloxacin, Crx-

Cefuroxime, Aug- Augmentin, x-zone of inhibition in mm, Strep sp-Streptococcus sp, Staph sp-Staphylococcus sp, CoNStaph $s p$ - Coagulase negative Staphylococcus $s p$

The resistance phenotype of isolates recovered from the fresh fish and smoked fish samples showed the least number of antibiotics that isolates were totally resistant to was five (5) and the highest number of antibiotics was eight (8). Table 5 and 6 shows the resistance phenotype of isolates recovered from the fresh and smoked fish samples. 
International Journal of Advances in Scientific Research and Engineering (ijasre), Vol 6 (4), April -2020

Table 5 Resistance phenotype of isolates from smoked fish samples

\begin{tabular}{|c|c|c|}
\hline Isolates & Antibiotics & Number \\
\hline Strep $s p$ & Caz, Crx, Gen,Ctr, Ery, Aug, Cxc & 7 \\
\hline Strep sp & Caz, Crx, Gen,Ctr, Ery,Aug, Cxc & 7 \\
\hline Strep sp & Caz, Crx, Gen,Ctr, Ery, Aug, Cxc & 7 \\
\hline Strep sp & Caz, Crx, Gen,Ctr, Ery ,Aug, Cxc & 7 \\
\hline Strep sp & Caz, Crx, Gen,Ctr, Ery Aug, Cxc & 7 \\
\hline Strep $s p$ & Caz, Crx, Gen,Ctr, Ery, Ofl,Aug, Cxc & 8 \\
\hline CoN Staph sp & Caz, Crx, Gen,Ctr, Ery, Ofl,Aug, Cxc & 8 \\
\hline Strep sp & Caz, Ofl, Gen,Ctr, Ery, Aug, Cxc & 7 \\
\hline CoN Staph sp & Caz, Crx, Gen,Ctr, Ery ,Aug, Cxc & 7 \\
\hline Strep sp & Caz, Crx, Gen,Ctr, Ery Aug, Cxc & 7 \\
\hline Strep sp & Caz, Crx, Gen,Ctr, Ery,Aug, Cxc & 7 \\
\hline Strep sp & Caz, Crx, Gen,Ctr, Ery,Aug, Cxc & 7 \\
\hline Strep sp & Caz, Crx , Gen,Ctr, Ery,Aug, Cxc & 7 \\
\hline Strep $s p$ & Caz, Crx, Gen,Ctr, EryAug, Cxc & 7 \\
\hline Strep sp & Caz, Crx, Gen,Ctr, Ery, Cxc & 6 \\
\hline Strep sp & Caz, Crx, Gen, Aug, Cxc, & 5 \\
\hline Staph sp & Caz, Gen,Ctr, Ery, Ofl,Aug, Cxc & 7 \\
\hline Strep sp & Caz, Crx, Gen,Ctr, Ofl,Aug, Cxc & 7 \\
\hline Strep sp & Caz, Gen,Ctr, Ofl,Aug, Cxc & 6 \\
\hline Strep $s p$ & Caz, Crx, Gen,Ctr, Ery, Aug, Cxc & 7 \\
\hline strep sp & Caz, Crx, Gen,Ctr,Aug, Cxc & 6 \\
\hline Strep $s p$ & Caz, Crx, Gen, Ctr, Ery,Aug, Cxc & 7 \\
\hline Strep sp & Caz, Crx, Gen,Ctr, Ery, Ofl,Aug, Cxc & 8 \\
\hline Strep sp & Caz, Crx, Gen, Ctr, Ery, Aug, Cxc & 7 \\
\hline Staph sp & Caz, Crx, Gen,Ctr, Ery, Ofl,Aug, Cxc & 8 \\
\hline Strep sp & Caz, Crx, Gen,Ctr, Ery Aug, Cxc & 7 \\
\hline Strep sp & Caz, Crx, ,Ctr, Ofl,Aug, Cxc & 6 \\
\hline Strep sp & Caz, Crx, Gen,Ctr,Aug, Cxc & 6 \\
\hline Strep sp & Caz, Crx, Gen,Ctr, Ery,Aug, Cxc & 7 \\
\hline Strep sp & Caz, Crx, Gen,Ctr, Ery,Aug, Cxc & 7 \\
\hline
\end{tabular}


International Journal of Advances in Scientific Research and Engineering (ijasre), Vol 6 (4), April -2020

Table 6 Resistance phenotype of isolates from frozen fish samples

\begin{tabular}{lll}
\hline Isolates & Antibiotics & Number \\
\hline Strep sp & Caz, Crx ,Ctr, Ery, Aug, Cxc & 6 \\
Strep sp & Caz, Crx,Ctr, Ery, Ofl, Aug, Cxc & 7 \\
Strep sp & Caz, Crx, Gen,Ctr, Ery, Ofl, Aug, Cxc & 8 \\
Strep sp & Caz, Crx, Gen,Ctr, Ery,Aug, Cxc & 7 \\
Staph sp & Caz, Crx, Ctr, Ery,Aug, Cxc & 6 \\
Strep sp & Caz, Crx , Gen,Ctr, Ery,Aug, Cxc & 7 \\
Strep sp & Caz,Ctr, Ofl,Aug, Cxc & 5 \\
Strep sp & Caz, Crx, Gen,Ctr, Ofl,Aug, Cxc & 7 \\
\hline
\end{tabular}

\subsection{DISCUSSION}

The results of the bacteriological status of both fresh and smoked fish are summarized with variations found in the total bacterial counts. The fresh fish samples had a minimum count of $1.7 \times 10^{6} \mathrm{cfu} / \mathrm{g}$ and a maximum count of $4.0 \times 10^{6} \mathrm{cfu} / \mathrm{g}$ while the smoked fish samples had a minimum count of $1.8 \times 10^{6} \mathrm{cfu} / \mathrm{g}$ and a maximum count of $8.5 \times 10^{6} \mathrm{cfu} / \mathrm{g}$. Results from this study show that the samples do not meet the acceptable limit of $5 \times 10^{5} \mathrm{cfu} / \mathrm{g}$ of the International Commission of Microbiological Specification for Food (ICMSF) [23]. This shows the microbiological quality of the frozen fishes and smoked fishes which is a public health concern. Reasons for the bad quality could be due to environmental air pollution, contamination by various hands touching the fish, and for the frozen fish it could get contaminated by not storing the fish at right temperature. The international institute of refrigeration recommends a storage temperature of fatty fish such as mackerel at $-24^{\circ} \mathrm{C}$ and cooked fish should be kept at a temperature of $140^{\circ} \mathrm{F}$ or higher to keep it outside the temperature zone in which bacteria, that causes food borne illness grows quickly [24]. "Reference [25]" reported different microbial counts in fish samples obtained from a Nigerian market with respect to environmental conditions (temperature and length of exposure) with highest viable counts obtained at room temperature $\left(25^{\circ} \mathrm{C}\right)$ and above 8hours of exposure (out of refrigeration). Therefore, keeping fish under atmospheric conditions or at room temperatures for a very long time is shown to predispose it to microbial deterioration.

The total viable count in the smoked fish samples was higher than that of the frozen samples. The presence and high number of the isolates could be explained by the fact that these organisms can withstand the adverse processing conditions and also the sanitary conditions under which the smoked fish samples are handled and kept [26, 27, 28].

Previous studies show various organisms have been isolated from fish samples. They include Staphylococcus aureus, Bacillus subtilis, Shigella sp, Staphylococcus epidermis, Streptococcus sp, Salmonella typhi, E.coli, Klebsiella sp and Proteus mirabilis $[27,28,29,30,31]$. The result of this study showed that Streptococcus $s p$ and Staphylococcus $s p$ as the only organisms isolated from the samples. The high number of Streptococcus $s p$ isolated from the samples is noteworthy. Previous reports worldwide have shown Streptococcal diseases in wild and farmed populations of diverse fresh water and marine fish [32, 33, 34]. In Nigeria, previous studies also confirm the isolation of Staphylococcus $s p$ and Streptococcus $s p$ alongside other bacteria from fish samples $[25,27,29]$.

The antibiotics susceptibility test showed high level of resistance in the isolates. "Reference [35]" reported antibiotic resistance among bacterial species isolated from the fish (Clarias gariepinus). "Reference [36]" reported multidrug resistant bacteria isolated from fresh fish and fish handlers in Maiduguri, Nigeria. A previous report also show the antibiotic sensitivity pattern of microorganisms isolated from smoked and frozen fishes sold in Benin and Warri Metropolis in Nigeria [37]. High levels of 
bacterial resistance to antibiotics are indications of abuse and misuse of antibiotics in the environment. Antibiotic resistant isolates have been isolated from fish farms especially farms with history of antibiotic use. When antibiotics are mixed with fish food, residual antibiotics may be found in fish products and fish meat. The use of antibiotics in the rearing of fish could be detrimental to the health of the fish and also that of animals and humans. Bacterial groups co-habiting a common environment may express a similar antibiotic sensitivity pattern if they share a common pool of R-factor plasmids [38]. The resistant bacteria may transfer resistance directly to humans or indirectly by transferring resistant determinants to other pathogenic bacteria of humans. The presence of highly resistant pathogens which are also human pathogens is a public health threat as these resistant bacteria may cause diseases in humans.

Also, the continuous pollution of the aquatic environment which is a situation more peculiar to rural settings like the Okada community in Edo state, Nigeria increases the likelihood of infection as untreated wastes are dumped on the grounds, washed away by rainwater and discharged into nearby water bodies and ponds [7]. The use of organic manure by fish farmers may contribute to antibiotic resistance of bacterial isolates from their farms and this occurs through the transfer of antibiotic residues and resistant bacteria to fish farms if the commercial farm from which the manure is sourced uses antibiotics [39].

Compliance with standard microbiological measures to prevent contamination by these organisms becomes very necessary and should be enforced. A global effort to curb the over-use of antibiotics in the rearing of fish is essential in preventing detrimental effects to fish, animal and human health. However, diseases from contaminated sea foods can be curtailed by preparing food hygienically. Political awareness and consumer education on food safety will help strengthen enforcement of food standards, improve hygienic practices, and prevent foodborne illnesses. In 2006, WHO introduced the five keys to safe foods. Each key contains a simple message that, when practiced, help prevent foodborne disease. The Five keys are: (keep clean, separate raw and cooked food, cook thoroughly, keep food at safe temperatures, use safe water and raw materials) and choose foods that have been produced without the use of antibiotics for growth promotion or disease prevention in healthy animals [40].

\subsection{CONCLUSION}

Considering the rapid growth and importance of the aquaculture industry in many regions of the world and the widespread, intensive, and often unregulated use of antibacterial agents for fish and shellfish production, additional efforts are required to prevent the development and spread of antibacterial resistance in aquaculture. Fish processors and vendors should improve handling hygiene and consumers should also cook smoked fish properly to minimise early spoilage and possible health hazards. Continuous monitoring of antibiotic resistant bacteria in fish samples will not only reduce the risk of diseases to the fishes but public health hazard to handlers and consumers in general. Aseptic and proper hygienic condition need to be maintained throughout all steps which include catching, transportation, processing, handling and preservation of retail fish samples. Prudent use of antibiotics in aquaculture should be promoted.

\section{REFERENCES}

[1]. FAO (2000) The State of World Fisheries and Aquaculture 2000. FAO, Rome, Italy.

[2]. Kapetsky, J.M. (1995) A first look at the potential condritsution of warm water fish farming to food security in Africa.

[3]. FAO/NACA/WHO(1999): Food Safety Issues Associated with products from Aquaculture. Report of a joint FAO/NACA/WHO study Group. WHO Technical Report series. 883.

[4]. FAO(1994): Food and Agriculture Organization of the United Nations: marine Fisheries: Review of state of the world Fishery Circular No 920, Rome.

[5]. WHO (2007): Food safety issues associated with products from Aquaculture. Report of a Joint FAO/NACA/WHO study Group, WHO Technical reprint Series: 883 + Geneva. Pany.

[6]. Yunxia, Q., Jiazhog, S. and Guoliang, W. (2001). A review of principal bacterial diseases of mariculture fish. Transact.Oceanol.Limnol. 2: 78-87.

[7]. Odiete, W.O. (1999): Environmental Physiolology of Animals and Pollution. Diversified Resources Ltd Lagos, 1st ed. pp187- 219ISBN978-028957-7.

[8]. Acar, J.F. and Moulin, G. (2006). Antimicrobial resistance at farm level. Rev Sci Tech OIE 25(2):775-92.

[9]. Adedeji, O.B., Tiamiyu, A.M. and Emikpe, B.O. (2011). The Antibiotics Resistance Patterns of Bacterial flora of fish from different Aquatic Environment from Ibadan, Southwest, Nigeria, Adv. Environ Biol. 5(8):2039-2047.

[10]. Sowunmi, A.A., Okunubi, M.A. and Efuntoye, MO. (2008). Occurrence of bacteria in gill and buccal cavity of Clarias gariepinus (Burchell, 1822) and Tilapia zilli (Gervais) from Lekki lagoon, Southwest Nigeria. Technique (International Office of Epizootics) 25(2):775-92. 
[11]. Kirubakaran, C.J.W., Alexander, C.P. and Michael, R.D. (2010). Enhancement of non-specific immune responses and disease resistance on oral administration of Nyctanthes arbortristis seed extract in Oreochromis mossambicus (Peters). Aquaculture. Res. 41, 1630-1639.

[12]. Alderman, D.J. and Hastings, T.S. (1998). Antibiotic use in aquaculture: development of antibiotic resistance potential for consumer health risks. Int. J. Food Sci. Technol. 33: 139-155.

[13]. Christensen, A.M., Ingersley, F. and Baun, A. (2006). Ecotoxicity of mixtures of antibiotics use in aquacultures. Environ. Toxicol. Chem. 25: 2208-2215.

[14]. Angulo, F.J. APUA Antimicrobial agents in aquaculture: potential impact on health. Newsletter. 18: 1-6.

[15]. Anderson, A.D., Nelson, J.M., Rossiter, S. and Angulo, F.J. (2003). Public health consequences of the use of antimicrobial agents in food animals in the United States. Microb. Drug Resist 9: 373-379.

[16]. Center for Food Safety and Applied Nutrition. (2001). Food and Drug Administration. 3rd edition, Washington pp.145166.

[17]. Yagoub, S.O. and Ahmed, T.M. (2004). Pathogenic Microorganisms in fresh water samples collected from Khartoum central market. Sudan J. Vet. Sci. Anim. Husbandry 43(1-2): 32-37.

[18]. Orji, J.O., Okonkwo, E.C., Umezulike, O.I. and Ayim, C.(2014). Survey of the microbiological quality of frozen fish marketed in Abakaliki Metropolis and its implication for consumer health. Int J Sci Res 3: 2277-8179.

[19]. Karthiga Rani, M., Chelladurai, G. and Jayanthi, G. (2016). Isolation and identification of bacteria from marine market fish Scomberomorus guttatus (Bloch and Schneider, 1801) from Madurai district, Tamil Nadu, India. J Parasit. Dis. 40(3):1062-1065. DOI 10.1007/s12639-014-0634-0.

[20]. Brown, E.A. (2005). Benson's Microbiological applications laboratory manual in general microbiology, 9th ed. New York: McGraw-Hill Companies Inc. pp. 230-80.

[21]. Bauer, A.W., Kirby, W.M.M., Sherirs, J.C. and Turck, M. (1966). Antibiotic susceptibility testing by standard single disk method. Am J Clin Pathol 45(4):433-96.

[22]. European Committee on Antimicrobial Susceptibility Testing. 2019. Breakpoint tables for interpretation of MICs and zone diameters. Version 9.0. http://www.eucast.org.

[23]. ICMSF (International Commission of Microbiological Specification for Food)(1986). Microorganisms in Food 2. Sampling for Microbiological Analysis: Principles and Specific Applications. University of Toronto Press, Toronto, Canada, 2nd edition.

[24]. IIR (International Institute of Refrigeration) (1986). Recommendations for the Processing and Handling of Frozen Foods. Paris.

[25]. Ezemba, C.C., Eze, S.O. and Archibong, E.J. (2017). Bacteriological Analysis of Iced Fish Retailed at Eke-Awka Market, Anambra State. IJRPB 4(8); 1-9

[26]. Adebayo-Tayo, B.C., Okonko, I.O., Esen, C.U., Odu, N.N., Onoh, C.C. and Igwiloh, N.J.P. (2011). Incidence of potentially pathogenic Vibrio spp. in Fresh Seafood from Itu Creek in Uyo, Akwa Ibom State, Nigeria. World Appl. Sci. J. 15(7): 985-991.

[27]. Ibrahim, B.U., Baba, J. and Sheshi, M.S. (2014). Isolation and Identification of Bacteria Associated with Fresh and Smoked Fish (Clarias gariepinus) In Minna Metropolis, Niger State. Nigeria. JAEM 2(3): 81-85 http://pubs.sciepub.com/jaem/2/3/4 DOI:10.12691/jaem-2-3-4.

[28]. Tiamiyu, A.M., Emikpe, B.O. and Adedeji, O.B. (2011): Isolation and identification of aerobic Bacteria Flora of the skin and stomach of wild and cultured Clarias gariepinus and Oreochromis niloticus from Ibadan Southwest Nigeria. J. appl. sci. res. 7(7): 1047-1051.

[29]. Amande, T.J. and Nwaka, S.U. (2013). Bacterial Flora of African Catfish (Clarias gariepinus) Harvested From Ponds In Uyo South-South Nigeria. IOSR-JESTFT 5(3): 72-76 e-ISSN: 2319-2402,p- ISSN: 2319-2399. www.Iosrjournals.Org

[30]. Ipki, G.U. and Offem, B.O. (2008). Bacterial infection of cultural fishes in the fish farm of the Cross River University of Technology. Egypt. J. Microbiol. 21: 57-63.

[31]. Moshood, A.Y. and TengkuHaziyamin, A.A. (2012). Isolation and Identification of Bcateria in Retailed Smoked Fish within Bauchi Metropolis. Jour. of Pharm. and Biol. Sciences. 3 (1): 1-5.

[32]. Kusuda, R. and Salati, F. (1993). Major bacterial diseases affecting mariculture in Japan. Annu. Rev. Fish Dis. 3: 69-85.

[33]. Salvador, R., Muller, E.E., César de Freitas, J., Leonhadt, J.H., Pretto-Giordano, L.G. and Dias, J.A. (2005). Isolation and characterization of Streptococcus spp. group B in Nile tilapias (Oreochromis niloticus) reared in hapas nets and earth nurseries in the northern region of Parana State, Brazil. Ciênc Rural, Santa Maria: 35(6): 1374-1378.

[34]. Seong-Won, N., Jun-ichi, H., Seong, B.P., Ho, B.J., In Seok, C., Motoshige, Y., Yoji, N., Atsushi, F., Motohiko, S., Kinya, K., Hidehiro, K., Ikuo, H., Haruko, T., Takashi, A. and Tae-Sung, J. (2013). Comparative Genomic Characterisation of Three Streptococcus parauberis Strains in Fish Pathogen, as Assessed by Wide-Genome Analyses. PLOS ONE 8(11): e80395. https://doi.org/10.1371/journal.pone.0080395. 
[35]. Ogunshe, A.A. and Olabode , P.O. (2009). Antimicrobial potentials of indigenous Lactobacillus strains on Gram-negative indicator bacterial species from Clarias gariepinus (Burchell, 1822): Microbial inhibition of fish-borne pathogens. Afr. J. Microbiol. Res. 3(12): 870-876.

[36]. Grema, H.A., Geidam, Y.A., Suleiman, A., Gulani, I.A. and Birma RB. (2015). Multi-Drug resistant bacteria isolated from fish and fish handlers in Maiduguri, Nigeria. J Anim Vet Adv 7(3): 49-54.

[37]. Imarhiagbe, E.E., Ofuya, M.E., Osarenotor, O. and Ekhaise, F.O. (2016). Antibiotic Sensitivity Pattern of Microorganisms Isolated from Smoked and Frozen Fishes Sold in Benin and Warri Metropolis. Nig J. Biotech. 31:(4045) ISSN: 01891731 Available online at http://www.ajol.info/index.php/njb/index and www.biotechsocietynigeria.org DOI: http://dx.doi.org/10.4314/njb.v31i1.6.

[38]. Spanggard, B., Jorgenses, F.G. and Huss, H.H. (1993). Antibiotic resistance in bacteria isolated from three freshwater farms and an unpolluted stream in Demark. Aquaculture 115: 195-207.

[39]. Elsaidy, N., Abouelenien, F. and Kirrella, G.A.K. (2015). Impact of using raw orfermented manure as fish feed on microbial quality of water and fish. Egypt J Aquat Res. 41:93-100.

[40]. WHO (2006) Five Keys to Safer Food Manual. WHO Library Cataloguing-in Publication Data. Department of food safety, zoonoses and foodborne diseases. NLM Classification: WA 695.

\section{CONFLICT OF INTEREST}

No conflict of interest is declared 